Japan. J. Med. Sci. Biol., 35, 97-104, 1982

\title{
NATURAL KILLER CELL ACTIVITIES OF SEVERAL INBRED STRAINS OF THE GUINEA PIG AND THEIR SUSCEPTI- BILITIES TO RABBIT ANTISERUM DIRECTED TO GUINEA-PIG BRAIN TISSUE
}

\author{
Tetsuro KATAOKA, Tsuneo KAMIYAMA*, TAKaO OHNUKI, \\ Mikio MIYAMOTO and TOHRU TOKUNAGA \\ Department of Tuberculosis and *Department of Veterinary Science, \\ National Institute of Health, Kamiosaki, Shinagawa-ku, Tokyo 141
}

(Received November 16, 1981. Accepted February 26, 1982)

\begin{abstract}
SUMMARY: Natural killer (NK) cell activities of spleen and peripheral blood leukocytes from several inbred guinea-pig strains, established in this Institute, were assessed in an $18-\mathrm{hr}{ }^{51} \mathrm{Cr}$-release assay. As target cells in the NK assay, a human myeloid cell line, K562, appeared to be the most suitable among several cultured cell lines tested. Intensities of cytolysis were different from strain to strain, but generally high in JY-2, JY-4 and JY-10 and low in JY-1. Treatment of the effector cells with rabbit anti-guinea-pig brain tissue serum plus complement reduced the NK activity, whereas treatment with rabbit anti-guinea-pig thymocyte serum, or rabbit anti-asialo GMI serum, plus complement showed no significant effect on the NK activity.
\end{abstract}

\section{INTRODUCTION}

Natural killer (NK) cells were first demonstrated in man (Takasugi, Mickey and Terasaki, 1973) and in mice (Kiessling, Klein and Wigzell, 1975; Sendo et al., 1975), and their significant role in host resistance to tumors or to infections has been widely recognized. The NK activity was demonstrated in most animal species, but detailed studies have been concentrated to the mouse and human; only few reports have dealt with guinea-pig NK cells (Altman and Rapp, 1978; Arnaud-Battandier, Bundy and Nelson, 1978; Ermein et al., 1980). It has been known that the NK activity is different depending upon the mouse strain (Blair, 1980) and that NK cells are susceptible to rabbit antiserum to either mouse brain-associated $T$ cell antigen (Habu et al., 1979) or a glycosphingolipid, asialo GM1 (Kasai et al., 1980). We attempted to find out whether or not these findings are true also in guinea pigs; we compared the NK activities of several inbred guinea-pig strains (JY series) established in this Institute (cited in: Chiba, Otokawa and Egashira, 1978; Kataoka and Tokunaga, 1979; Asano, Minobe and Nakagawa, 1981), and tested the guinea pig NK cells for suscep-

片岡哲朗・大抜隆雄・宮本幹夫・徳永 徹（国立予防衛生研究所 結核部） 神山恒夫（国立予防衛生研究所 丵疫部） 
tibilities to antiserum against guinea-pig brain tissues and that against asialo GM1.

\section{Materials ANd Methods}

Animals: Inbred guinea pigs of strains JY-1, JY-2, JY-4, JY-7, JY-10 and $(J Y-4 \times J Y-10)$ F1 were obtained from the Department of Veterinary Science, National Institute of Health, Tokyo. These inbred strains were established by Drs. H. Yoda, T. Nakano, and M. Nakagawa in that Department from random-bred guinea pigs obtained in 1949 from the Rockland Farm, U.S.A. Inbred strain-2 and strain-13 guinea pigs and outbred Hartley guinea pigs were purchased from Nippon Institute for Biological Science (Ohme, Tokyo), and Funabashi Farms Co. (Funabashi, Chiba), respectively. Both male and female animals were bred conventionally and used at the age of around 10 weeks. Rabbits (Japanese white) weighing about $3 \mathrm{~kg}$ were purchased from Nihon Ikagakuzairyo Co. (Tokyo).

Effector cells: Spleens were removed aseptically into cold Hanks' buffered salt solution (HBSS) and teased apart on a stainless steel mesh (\#200) by gentle pressing with a spatula. Packed spleen cells were suspended in sterile distilled water for $10 \mathrm{sec}$ and then added was an equal volume of double-strength HBSS to lyse erythrocytes. Heparinized blood, drawn from the heart, was layered over a 0.33 volume of a Ficoll-Hypaque solution (LSM reagent; Litton Bionetics, Kensington, MD, U.S.A.) in a 5-ml glass tube and centrifuged at $400 \times \mathrm{g}$ for $30 \mathrm{~min}$ at $20 \mathrm{C}$. The cells at the interface were collected and diluted with HBSS. All these cells were washed three times with HBSS.

Target cells: The cultured cell lines used were: guinea-pig macrophagelike cell line K3 (Kato et al., 1981) and simian virus 40-transformed cells of strain 13 (STC13) or strain JY-1 (SV-JY 1) guinea-pig kidney cells gifted by Dr. K. Kato, Department of Enteroviruses of this Institute; mouse-derived YAC-1 (Sjögren and Hellström, 1965) and RLô 1 (Sendo et al., 1975); and humanoriginated K562 (Lozzio and Lozzio, 1973). All cells were maintained in RPMI 1640 medium (Nissui Seiyaku, Co., Tokyo) supplemented with $10 \%$ fetal calf serum (FCS; Grand Island Biological Co., Grand Island, NY, U.S.A.), 100 units $/ \mathrm{ml}$ penicillin and $100 \mu \mathrm{g} / \mathrm{ml}$ streptomycin.

Preparation of antisera: As immunogens, thymocyte and brain homogenates of Hartley guinea pigs were suspended in HBSS and emulsified with Freund's complete adjuvant containing $0.5 \mathrm{mg} / \mathrm{ml}$ tubercle bacilli. Rabbits were immunized intradermally with the emulsion containing $2 \times 10^{8}$ thymocytes or $1 \mathrm{~g}$ of brain tissue. The animals were boosted with two iv injections with $1 \times 10^{8}$ thymocytes suspended in $3 \mathrm{ml} \mathrm{HBSS}$ at a 2-week interval or two sc injections with $1 \mathrm{~g}$ brain homogenate on days 7 and 21 . Two to three weeks after the last injection, the animals were sacrificed. Sera were inactivated by heating at $56 \mathrm{C}$ for $45 \mathrm{~min}$.

The serum was mixed with an equal volume of packed guinea-pig erythro- 
cytes, incubated at $4 \mathrm{C}$ for $60 \mathrm{~min}$, and then separated from the erythrocytes by centrifugation. This procedure was repeated four times. Then the serum was absorbed with an equal volume of packed $\mathrm{EN}-\mathrm{L}_{2} \mathrm{C}$ cells (B cell leukemia of a strain 2 guinea pig kindly gifted by Dr. E. M. Shevach, Laboratory of Immunology, National Institute of Allergy and Infectious Diseases, Bethesda, MD, U.S.A.) five times in similar manner. The absorbed sera were millipored and stored at $-20 \mathrm{C}$.

Rabbit anti-asialo GMI serum was prepared and given by Dr. M. Kasai, Department of Tuberculosis of this Institute, as ammonium sulfate precipitate of whole antiserum of the rabbits injected repeatedly with purified asialo GMI in Freund's complete adjuvant (Kasai et al., 1980).

These preparations were tested for the complement-dependent cytolytic activities against spleen cells, lymphnode cells, thymocytes, and bone marrow cells of a Hartley guinea pig and EN- $\mathrm{L}_{2} \mathrm{C}$ cells by the ${ }^{51} \mathrm{Cr}$-release assay described by Shevach, Rosenstreich and Green (1973).

Treatment of effector cells with antisera: A suspension of $2 \times 10^{6}$ spleen cells $/ \mathrm{ml}$ was mixed with an equal volume of a diluted antiserum and incubated at room temperature for $45 \mathrm{~min}$. The cells were washed once, resuspended in the original volume of fresh guinea-pig serum (1:2 dilution) and then incubated $37 \mathrm{C}$ for $30 \mathrm{~min}$. The mixture was centrifuged and the cells were washed three times with RPMI 1640 medium and resuspended in the original volume of the medium.

Microcytotoxicity assay: Five to 10-million target cells were labeled with $100 \mu \mathrm{Ci} / \mathrm{ml}$ of sodium ${ }^{51} \mathrm{Cr}(51 \mathrm{mCi} / \mathrm{mg}$, Japan Radioisotope Association, Tokyo) for $60 \mathrm{~min}$. The target $\left(1 \times 10^{4}\right.$ unless otherwise noted) and the effector cells were mixed in a well of a round bottomed microplate (A/S Nunc, Roskilde, Denmark) to a final volume of $0.2 \mathrm{ml}$. The plate was spun at $200 \times \mathrm{g}$ for $2 \mathrm{~min}$ and incubated in $5 \% \mathrm{CO}_{2}$ in a humidified incubator for 4 and $18 \mathrm{hr}$ at $37 \mathrm{C}$. The supernatants were harvested with the Titerteck supernatant collection systems (Flow Laboratories, Rockville, MD, U.S.A.) and counted in a gamma counter (Packard Instruments Co., Inc., Downers Glove, IL, U.S.A.). The count was made with triplicate samples. The $\%$ cytotoxicity was calculated as follows:

$$
\% \text { Gytotoxicity }=\frac{\text { Experimental count }(\mathrm{cpm})-\text { Minimum count }(\mathrm{cpm})}{\text { Maximum count }(\mathrm{cpm})-\text { Minimum count }(\mathrm{cpm})} \times 100
$$

Maximum and minimum counts were made by incubation of the target cells alone in $0.1 \%$ sodium dodesyl sulfate (SDS) and in test medium, respectively.

Statistical analysis: Student's $t$ assay was employed to analyze the results.

\section{Results}

First, we searched optimal conditions for assaying the guinea-pig NK activity using spleen leukocytes from Hartley guinea pigs as effector cells and cells of lines K562, RLô 1 and YAC-1 as target cells. The target cells were known to 
TABLE I

Natural cytotoxicity of Hartley guinea-pig spleen cells against different target cells

\begin{tabular}{|c|c|c|c|c|c|}
\hline \multirow{2}{*}{ Exp. No. } & \multirow{2}{*}{$\begin{array}{l}\text { Incubation } \\
\text { period (hr) }\end{array}$} & \multirow{2}{*}{$\begin{array}{l}\text { Target } \\
\text { cell }\end{array}$} & \multicolumn{3}{|c|}{ Cytotoxicity (\%) } \\
\hline & & & $\mathrm{E} / \mathrm{T}=25$ & 50 & 100 \\
\hline \multirow{6}{*}{1} & \multirow{3}{*}{4} & K562 & 0.8 & 2.4 & 7.6 \\
\hline & & YAC-1 & 1.7 & 1.1 & 3.5 \\
\hline & & RL今 1 & 2.4 & 4.2 & 5.9 \\
\hline & \multirow{3}{*}{18} & K562 & 10.3 & 13.7 & 22.9 \\
\hline & & YAC-1 & -2.4 & -0.4 & 6.1 \\
\hline & & RL今 1 & -2.5 & -0.4 & 6.8 \\
\hline \multirow{4}{*}{2} & \multirow{4}{*}{18} & K562 & 7.8 & 12.7 & 21.1 \\
\hline & & K3 & 7.9 & 6.7 & 10.6 \\
\hline & & STC13 & $\mathrm{NT}^{*}$ & NT & -6.0 \\
\hline & & SV-JY1 & NT & NT & 1.2 \\
\hline
\end{tabular}

* NT: Not tested.

be susceptible to human and mouse NK cells. The effector and ${ }^{51} \mathrm{Cr}$-labeled target cells were incubated for 4 or $18 \mathrm{hr}$ at effector to target $(\mathrm{E} / \mathrm{T})$ ratios of 25, 50, and 100 (Exp. 1 of Table I). It was indicated that significant lysis occurs only in the system using $\mathrm{K} 562$ as the target and an incubation period of $18 \mathrm{hr}$. RLô 1 and YAC-1 cells showed much lower sensitivity to guinea-pig NK cells.

Next, we surveyed guinea-pig-originated target cells for availability for guinea-pig NK assay. Cultured cell lines of K3, STC13 and SV-JY 1 were tested for their susceptibilities to NK cytolysis with spleen leukocytes from Hartley, strain 2, strain 13 and strain JY-1 guinea pigs. None of these target cells was lysed significantly by 18 -hr incubation with the effectors even at an $\mathrm{E} / \mathrm{T}$ ratio of 100 (Exp. 2 of Table I). Susceptibilities of the guinea-pig target cells were lower than that of K562 cells to guinea-pig NK cells. Therefore, we used K562 in $18 \mathrm{hr}{ }^{51} \mathrm{Cr}$-release assay for further experiments.

The spleen and peripheral blood leukocytes obtained from several inbred guinea-pig strains of JY series were tested for the NK activities (Table II). It seems that there is strain difference in the $\mathrm{NK}$ activity, though the intensities of cytolysis varied among the individuals of the same strain. The strains with high NK activities were JY-2, JY-4 and JY-10, and that with a low activity was JY-1. Strain 2 guinea pigs seemed to have an intermediate activity. The cytotoxicities were comparable between spleen and peripheral blood effector cells in all strains except JY-4.

Splenic effector cells from Hartley strain guinea pigs were treated with each antiserum and complement before the NK assay. The pretreatment of the effector cells with rabbit anti-guinea-pig thymocytes serum and complement did not change the NK activity (Table III). On the contrary, the pretreatment 

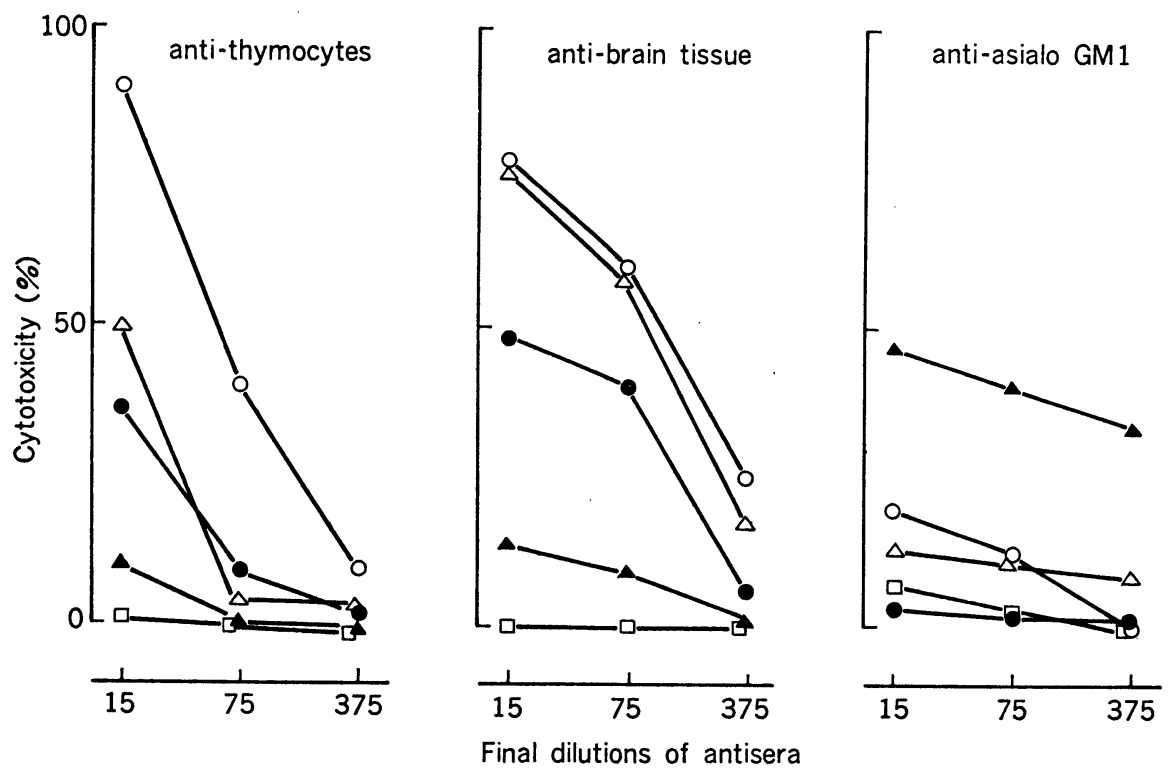

Fig. 1. Specificities of rabbit anti-guinea-pig thymocytes, anti-guinea-pig brain tissue, and anti-asialo GM1 sera.

A $100-\mu 1$ portion of each of $1 \times 10^{8} / \mathrm{ml}{ }^{51} \mathrm{Cr}$-labeled guinea-pig thymocytes (O), lymphnode cells $(\triangle)$, spleen cells $(\bullet)$, bone marrow cells $(\Delta)$ and EN- $\mathrm{L}_{2} \mathbf{C}$ leukemia cells $(\square)$, was mixed with $100 \mu 1$ of an indicated dilution of antiserum and fresh guinea-pig serum ( $1: 2$ dilution) in a well of 96 -well round bottomed microplates. The mixtures were incubated in a $\mathrm{CO}_{2}$ incubator at $37 \mathrm{C}$. After $45 \mathrm{~min}$, the plates were centrifuged at $500 \times \mathrm{g}$ for $10 \mathrm{~min}$ and a $100-\mu \mathrm{l}$ aliquot was transferred from each well into a plastic tube, which was counted in an autogramma spectrophotometer (Packard Instruments Inc.). The percentage cytotoxicity was calculated by the following equation:

$$
\frac{\text { cpm in wells with antiserum }- \text { cpm in wells with medium }}{\text { cpm in wells with SDS }- \text { cpm in wells with medium }} \times 100
$$

Each point expresses the mathematical mean of triplicate wells.

with rabbit anti-guinea-pig brain tissue serum plus complement reduced the NK activity remarkably. The pretreatment with anti-asialo GM1 plus complement did not significantly reduce the NK activity.

\section{Discussion}

In the present study, we first tested various target cell lines, including human, murine and guinea-pig tumor cells, for their susceptibilities to the splenic effector cells. Among them, only human myeloid cell K562 showed a relatively high and constant susceptibility to the NK cells, as reported by Altman and Rapp (1978). Other two groups of workers employed other humanderived tumor cell lines as the target (Arnaud-Battandier et al., 1978; Ermein et al., 1980). In all of these reports, an incubation period for longer than $18 \mathrm{hr}$ 
TABLE II

NK activities of several inbred strains of guinea pig

\begin{tabular}{|c|c|c|c|c|c|c|c|c|}
\hline \multirow[t]{3}{*}{ Exp. No. } & \multirow[t]{3}{*}{ Strain } & \multirow{3}{*}{$\underset{\text { No. }}{\text { Animal }}$} & \multicolumn{6}{|c|}{ Cytotoxicity (\%) } \\
\hline & & & \multicolumn{3}{|c|}{ Spleen cells } & \multicolumn{3}{|c|}{ Peripheral blood leukocytes } \\
\hline & & & $\mathrm{E} / \mathrm{T}=25$ & 50 & 100 & $\mathrm{E} / \mathrm{T}=25$ & 50 & 100 \\
\hline \multirow[t]{22}{*}{1.} & JY 1 & 1 & 1.8 & 1.4 & 3.1 & 2.9 & 4.7 & 5.1 \\
\hline & & 2 & 5.7 & 4.4 & NT & 5.5 & 5.0 & NT \\
\hline & & 3 & 5.3 & 6.4 & NT & 6.3 & 8.0 & 8.8 \\
\hline & & 4 & -0.8 & -0.2 & NT & 6.0 & 7.1 & 8.1 \\
\hline & JY 2 & 1 & 12.5 & 20.1 & 31.7 & 37.6 & 38.2 & NT \\
\hline & & 2 & 19.5 & 34.6 & 52.2 & 12.7 & 20.2 & 27.9 \\
\hline & & 3 & 18.7 & 33.6 & 50.0 & 23.4 & 27.4 & NT \\
\hline & JY 4 & 1 & 20.4 & 31.6 & 25.5 & 1.4 & 0.8 & 6.4 \\
\hline & & 2 & 16.5 & 18.4 & 26.6 & 4.6 & 6.2 & 2.7 \\
\hline & & 3 & 13.5 & 25.6 & 42.6 & NT & NT & NT \\
\hline & JY 7 & 1 & 3.4 & 1.6 & -1.3 & -4.7 & -5.2 & -7.7 \\
\hline & & 2 & 12.3 & 19.0 & 30.6 & 7.1 & 17.0 & 17.4 \\
\hline & & 3 & -0.8 & -1.3 & 1.1 & 0.8 & 6.6 & 0.3 \\
\hline & JY 10 & 1 & 7.5 & 14.5 & 26.0 & 7.1 & 17.7 & 17.6 \\
\hline & & 2 & 8.7 & 9.9 & 19.6 & 11.9 & 8.0 & 12.9 \\
\hline & & 3 & 4.7 & 10.0 & NT & 7.5 & 7.5 & NT \\
\hline & & 4 & 11.8 & 20.4 & NT & 15.1 & 18.1 & NT \\
\hline & $(J Y 4 \times J Y ~ 10)$ & ) 1 & 15.4 & 19.4 & 33.9 & 3.0 & 8.1 & 13.9 \\
\hline & & 2 & 15.2 & 11.0 & 30.5 & 6.0 & 10.1 & 12.4 \\
\hline & Strain 2 & 1 & 12.9 & 16.0 & 18.7 & 10.1 & 7.0 & NT \\
\hline & & 2 & 10.3 & 13.0 & 16.7 & 9.0 & 11.1 & 15.8 \\
\hline & & 3 & 3.1 & 7.0 & 7.5 & 16.5 & 18.7 & 28.0 \\
\hline \multirow{5}{*}{2.} & & & \multicolumn{4}{|c|}{ Spleen cells } & & \\
\hline & & & $\mathrm{E} / \mathrm{T}=20$ & 40 & 80 & 160 & 320 & \\
\hline & JY 1 & 5 & 3.2 & 2.7 & 7.9 & 4.0 & 2.8 & \\
\hline & & 6 & 3.8 & 3.6 & 4.7 & 5.1 & 3.5 & \\
\hline & & 7 & 3.4 & 2.9 & 5.0 & 4.3 & 3.0 & \\
\hline
\end{tabular}

K562 cells were used as the target cells.

NT: Not tested.

was required to detect significant $\mathrm{NK}$ activity. The cytotoxic mechanism of guinea-pig NK cells may be different from those of human and mouse NK cells, because 4-hr incubation is enough to detect significantly high NK activities of those species.

Possible contribution of macrophages to the cytotoxicity detected in the system can be excluded by the following facts: when ${ }^{51} \mathrm{Cr}$-labeled K562 cells were incubated with mineral oil-induced peritoneal adherent cells at E/T 20 
TABLE III

Effects of treatment of effector cells with anti-thymocytes, anti-brain or anti-asialo GM1 plus complement on guinea-pig NK activity

\begin{tabular}{|c|c|c|c|c|c|}
\hline $\begin{array}{l}\text { Experiment } \\
\text { No. }\end{array}$ & Treatment & $\begin{array}{c}\text { Serum } \\
\text { dilution }\end{array}$ & $\begin{array}{c}\text { Cytotoxicity } \\
(\%)\end{array}$ & $\begin{array}{c}\text { Reduction } \\
\text { in } \mathrm{NK} \text { activity } \\
(\%)\end{array}$ & $\mathrm{t}$-assay* \\
\hline \multirow[t]{5}{*}{1} & $\mathrm{C}^{\prime}$ alone & & 28.3 & & \\
\hline & Anti-thymocytes & $1: 20$ & 26.8 & 5.2 & NS \\
\hline & $+\mathrm{C}^{\prime}$ & $1: 40$ & 25.7 & 9.2 & NS \\
\hline & Anti-brain & $1: 20$ & 14.6 & 48.3 & $<0.01$ \\
\hline & $+\mathrm{C}^{\prime}$ & $1: 40$ & 22.2 & 21.6 & $<0.01$ \\
\hline \multirow[t]{5}{*}{2} & $\mathrm{C}^{\prime}$ alone & & 34.9 & & \\
\hline & Anti-brain & $1: 20$ & 26.8 & 23.2 & $<0.05$ \\
\hline & $+\mathrm{C}^{\prime}$ & $1: 40$ & 27.9 & 20.1 & NS \\
\hline & Anti-asialo GMI & $1: 20$ & 38.1 & -9.2 & NS \\
\hline & $+\mathrm{C}^{\prime}$ & $1: 40$ & 41.0 & -17.4 & NS \\
\hline
\end{tabular}

Spleen cells of a Hartley guinea pig were treated with or without an antiserum plus complement, then mixed with ${ }^{51} \mathrm{Cr}$-labeled $\mathrm{K} 562$ cells at an $\mathrm{E} / \mathrm{T}$ ratio of 100 .

Cytotoxicity obtained by untreated spleen cells were $29.1 \%$ (exp. 1) and $36.7 \%$ (exp. 1).

* P-value, NS: Not significant.

or 40 for $18 \mathrm{hr},{ }^{51} \mathrm{Cr}$-release into the culture supernatant was not greater than that with K562 cells alone. This was consistent with the reports of Altman and Rapp (1978) and Arnaud-Battandier et al. (1978).

Some fluctuations in individuals of the same strain were observed, especially in JY-7. Since the animals used in this study were bred under conventional conditions, the influence of environmental factor(s) on the NK activity must be considered. The animals were kept carefully in the same breeding room and were sacrificed at almost the same age after birth, however, a tendency different cytolytic activities among the strains, especially a low activity in strain JY-1, was always observed in repeated experiments. Altman and Rapp (1978) also noticed that the strain 2 guinea pig had NK activity significantly higher than strain 13. In the mouse (Blair, 1980) and rat (Shellam and Hogg, 1977) systems, the presence of such a strain with a high or low NK activity has also been indicated.

The treatment with anti-brain serum plus complement considerably reduced the NK activity, whereas that with anti-thymocyte and complement did not, coinciding with the results with the mouse NK system (Habu et al., 1979). However, it must be considered that anti-thymocyte and anti-brain-tissue sera used in our experiments are not specific enough, differing from anti-Thy 1 and anti-brain-associated $\theta$ antigen in the mouse system. The treatment with rabbit anti-asialo GM1 serum plus complement did not affect the guinea-pig NK activity, while this antiserum eliminated the mouse NK activity (Kasai et al., 1980). It was found by enzyme-linked immunosorbent assay that the anti-brain 
serum used here contained large amounts of both anti-asialo GMl and anti-GMl antibodies and moderate amounts of both anti-guinea-pig brain lipid and antiForssman antigen antibodies ( $T$. Momoi, personal communication). Therefore, it seems that the guinea-pig NK cells are not sensitive to anti-asialo GM1 serum, indicating that glycolipids on the NK-cell surface are different between guinea pigs and mice.

\section{Acknowledgements}

The authors thank Drs. M. Nakagawa and T. Asano, Department of Veterinary Science of this Institute, for supplying inbred guinea pigs and Miss M. Takegawa and Mrs. N. Katsu for their technical assistance. This work was partly supported by Research Grants from the Ministry of Health and Welfare, and Grants-in-Aid for Cancer Research from the Ministry of Education, Science and Culture of Japan.

\section{REFERENCES}

Altman, A. And Rapp, H. J. (1978): Natural cell-mediated cytotoxicity in guinea pigs: Properties and specificity of natural killer cells. J. Immunol., 121, 2244-2252.

Arnaud-Battandier, F., Bundy, B. M. ANd Nelson, D. L. (1978): Natural killer cells in guinea pig spleen bear Fc receptors. Europe. J. Immunol., 8, 400-406.

Asano, T., Minobe, Y. And Nakagawa, M. (1981): Polymorphism of serum protein in guinea pigs of inbred strains. Exptl. Animal, 30, 41-46.

BlaIR, P. B. (1980): Immunogenetics of natural immunity. p. 401-415. In R. B. HERBERMAN [ed.], Natural Cell-Mediated Immunity Against Tumors. Academic Press, New York.

Chiba, J.. Otokawa, M. And Egashira, Y. (1978): Serological studies on the major histocompatibility complex of new inbred strains of guinea pig. Microbiol. Immunol., 22, 545-555.

Ermein, O., Coombs, R. R. A., Ashby, J. ANd Plumb, D. (1980): Natural cytotoxicity in the guinea pig: The natural killer (NK) cell activity of the Kurloff cell. Immunology, 41, 367378.

Habu, S., Hayakawa, K., Okumura, K. and Tada, T. (1979): Surface markers on natural killer cells of the mouse. Europe. J. Immunol., 9, 938-942.

Kasai, M., Ifamori, M., Nagai, Y., OKumura, K. And Tada, T. (1980): A glycolipid on the surface of mouse natural killer cells. Europe. J. Immunol., 10, 175-180.

Kataoka, T. and Tokunaga, T. (1979): Restriction by the major histocompatibility complex of antigen-induced $\mathbf{T}$ lymphocyte proliferation in new inbred guinea pig strains. Microbiol. Immunol., 23, 197-205.

Kato, K., Kataoka, T., Ohnuki, T. and Tokunaga, T. (1981): Establishment of macrophagelike cell lines of the guinea pig. Microbiol. Immunol., 23, 197-205.

Kiessling, R., Klein, E. ANd Wigzell, H. (1975): "Natural" killer cells in the mouse. I. Cytotoxic cells with specificity for mouse Moloney leukemia cells. Europe. J. Immunol., 5, 112117.

Lozzio, C. B. AND Lozzio, B. B. (1973): Cytotoxicity of a factor isolated from human spleen. J. Nat. Cancer Inst., 50, 535-538.

Sendo, F., Aoki, T., Boyse, E. A. And Buofo, C. K. (1975): Natural occurrence of lymphocytes showing cytotoxic activity to $\mathrm{BALB} / \mathrm{c}$ radiation-induced leukemia $\mathrm{RL}$ ○l cells. J. Nat. Cancer Inst., 55, 603-609.

Shellam, G. R. AND Hogg, N. (1977): Gross virus-induced lymphoma in the rat. IV. Cytotoxic cells in normal rats. Int. J. Cancer, 19, 212-224.

Shevach, E. M., Rosenstreich, D. L. And Green, I. (1973): The distribution of histocompatibility antigens on $T$ and $B$ cells in the guinea pig. Transplantation, 16, 126-133.

SJögren, H. O. AND Hellström, I. (1965): Induction of polyoma specific transplantation antigenicity in Moloney leukemia cells. Exptl. Cell Res., 40, 208-212.

Takasugi, M., Mickey, M. R. And Terasaki, P. I. (1973): Reactivity of lymphocytes from normal persons or cultured tumor cells. Cancer Res., 33, 2898-2902. 